\title{
EVALUATION OF FUNCTIONING OF MITOCHONDRIAL ELECTRON TRANSPORT CHAIN WITH NADH AND FAD AUTOFLUORESCENCE
}

\author{
H. V. DANYLOVYCH \\ Palladin Institute of Biochemistry, National Academy of Sciences of Ukraine, Kyiv; \\ e-mail: danylovych@biochem.kiev.ua
}

We prove the feasibility of evaluation of mitochondrial electron transport chain function in isolated mitochondria of smooth muscle cells of rats from uterus using fluorescence of NADH and FAD coenzymes. We found the inversely directed changes in FAD and NADH fluorescence intensity under normal functioning of mitochondrial electron transport chain. The targeted effect of inhibitors of complex I, III and IV changed fluorescence of adenine nucleotides. Rotenone $(5 \mu \mathrm{M})$ induced rapid increase in NADH fluorescence due to inhibition of complex I, without changing in dynamics of FAD fluorescence increase. Antimycin A, a complex III inhibitor, in concentration of $1 \mu \mathrm{g} / \mathrm{ml}$ caused sharp increase in NADH fluorescence and moderate increase in FAD fluorescence in comparison to control. $\mathrm{NaN}_{3}(5 \mathrm{mM})$, a complex IV inhibitor, and CCCP $(10 \mu M)$, a protonophore, caused decrease in NADH and FAD fluorescence. Moreover, all the inhibitors caused mitochondria swelling. NO donors, e.g. $0.1 \mathrm{mM}$ sodium nitroprusside and sodium nitrite similarly to the effects of sodium azide. Energy-dependent $\mathrm{Ca}^{2+}$ accumulation in mitochondrial matrix (in presence of oxidation substrates and Mg-ATP2- complex) is associated with pronounced drop in NADH and FAD fluorescence followed by increased fluorescence of adenine nucleotides, which may be primarily due to $\mathrm{Ca}^{2+}-$ dependent activation of dehydrogenases of citric acid cycle. Therefore, the fluorescent signal of FAD and $N A D H$ indicates changes in oxidation state of these nucleotides in isolated mitochondria, which may be used to assay the potential of effectors of electron transport chain.

Key words: mitochondrial electron transport chain, NADH, FAD, fluorescence, inhibitors, myometrium of rats.

$\mathrm{M}$ itochondria are the key players of cell energy metabolism, programmed cell death and oxidative stress. Polarography with Clark electrode is a widely used method for evaluation of functional activity of mitochondria through measurement of oxygen consumption rate by suspension of the organelles of permeabilized cells in various functional states [1-5]. This method requires specific equipment and large quantities of experimental material, yet it does not provide information on the biochemical processes underlying changes in mitochondrial oxygen consumption. Therefore, research and development of simple, reliable and informative biochemical approaches to evaluation of functional activity of particular complexes of mitochondrial electron-transport chain are needed.

NADH (nicotinamide adenine dinucleotide) and $\mathrm{FADH}_{2}$ (flavin adenine dinucleotide) are the primary electron carriers within mitochondrial electron transport chain (ETC) (Fig. 1). NADH and $\mathrm{FADH}_{2}$ oxidation leads to translocation of protons through complexes I, III and IV of the mitochondrial inner membrane into intermembrane space. Proton gradient and ADP control rate of ATP synthesis by mitochondria. Thus, changes in redox state of NADH and $\mathrm{FADH}_{2}$ are indicators of mitochondria energetics [6-8].

$\mathrm{NADH}$ is essential as a coenzyme in catalytic reactions of the primary metabolic pathways and also is a dominant component of cellular autofluorescence. After it has donated electrons, primary to the mitochondrial ETC, $\mathrm{NAD}^{+}$does not fluoresce. Unlike NADH, $\mathrm{FADH}_{2}$ has no intrinsic fluorescence and FAD has it, which allows for visualization of redox state of these nucleotides using optical methods without employing fluorescent probes. Therefore, changes in fluorescence of pyridine and flavin nucleotides may be used to evaluate mitochondria energy-generating efficiency [8-10]. 
Evaluation of redox state of pyridine nucleotides is widely used in biochemical research, in particular in studies on consequences of oxidative stress [11-13], cell death detection [8], estimation of level of postsynaptic neuronal activation [10, 14]. The corresponding experiments were made on carcinoma cells [15], lung cells [16], heart tissue [17-19]. Changes in redox state of pyridine nucleotides as the primary cause of disruptions in mitochondrial respiration under fluoroacetate toxicity have been studied on ascitic Ehrlich carcinoma and rat liver mitochondria [20].

NADH has been described to fluoresce at 450$460 \mathrm{~nm}$ on excitation at $340-350 \mathrm{~nm}$. FAD emits at $530-540 \mathrm{~nm}$ on excitation at $450 \mathrm{~nm}[21,22]$. The amount of data on changes in fluorescent signal of NADH under influence of ETC effectors in isolated mitochondria $[5,12,20,23]$ is limited, and there is no data on changes in FAD signal. There is also no information on the corresponding studies on smooth muscle cell and mitochondria.
Thus, the aim of the present study was to investigate NADH and FAD fluorescence as biomarker for evaluation of functioning of isolated mitochondria (in the case of myometrium of rats) under the effect of modifiers of ETC and ion transport.

\section{Materials and Methods}

Mitochondria isolation from myometrium. Mitochondria samples were isolated from myometrium of non-pregnant rats by differentiation centrifugation, as described [24]. Rats were anesthetized by diethyl ether inhalation and decapitated. The animal experiments were conducted in accordance with guidelines of the European Convention for the Protection of Vertebrate Animals used for Experimental and Other Scientific Purposes (Strasbourg, 1986).

For the duration of the experiment the isolated mitochondria fraction was kept on ice. Protein content in mitochondria fraction was determined by the standard procedure after Bradford [25]. The mean content was $2 \mathrm{mg} / \mathrm{ml}$.

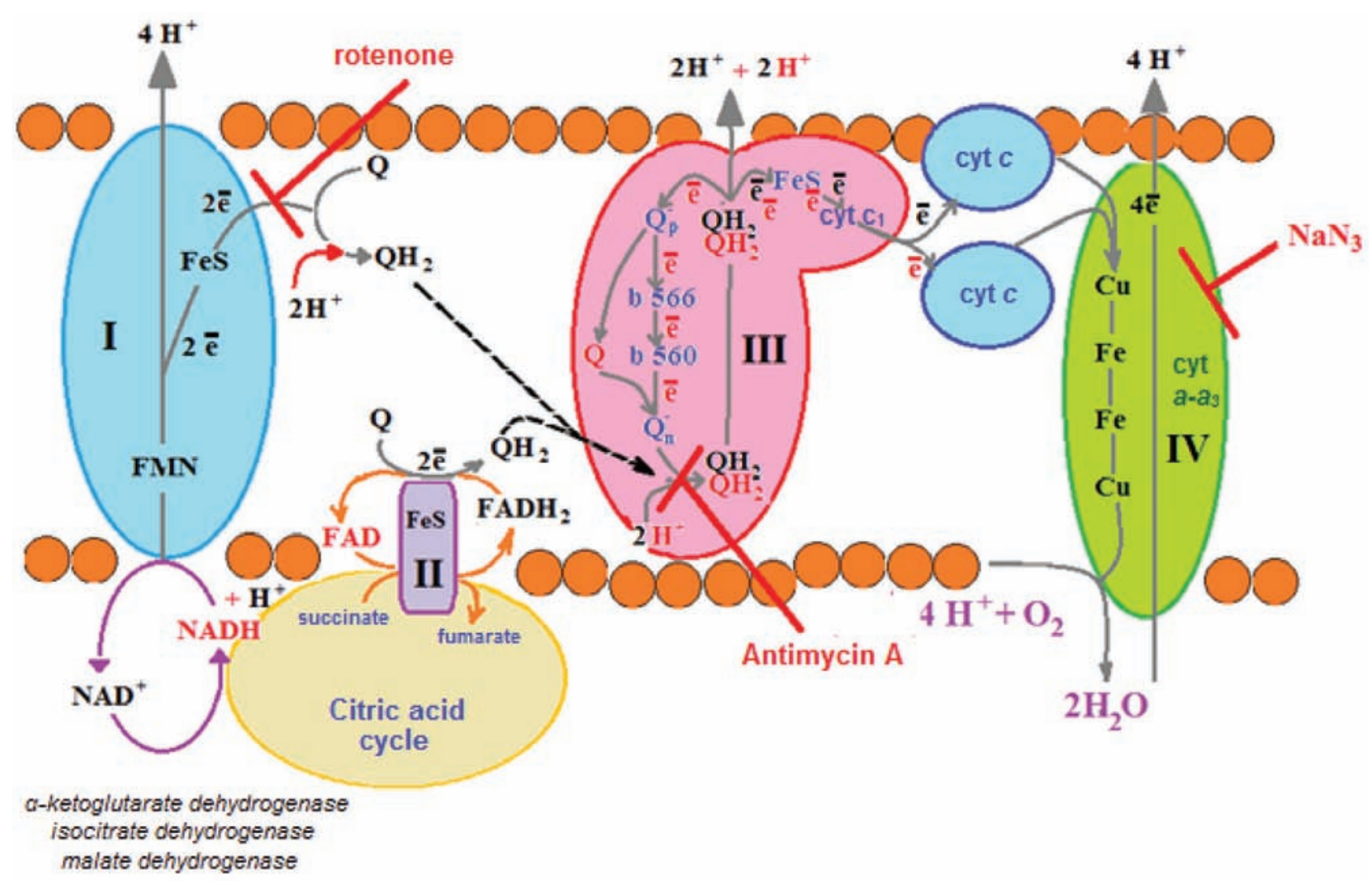

Fig. 1. Electron transfer and inhibitors of respiratory complexes in electron transport chain of mitochondria. Complex I - NADH-ubiquinone oxidoreductase, II - succinate dehydrogenase, III - ubiquinone-cytochrome-c oxidoreductase, $\mathrm{IV}$ - cytochrome c oxidase, $\mathrm{Q}$ - ubiquinone, $\mathrm{QH}_{2}$ - ubiquinol. Original diagram 
Detection of NADH and FAD fluorescence in mitochondria using spectrofluorometry. The relative values of NADH and FAD intrinsic fluorescence were determined with Quanta Master PTI (Canada) using FelixGX 4.1.0.3096 software. The detection was done in $2 \mathrm{ml}$ of the following medium: $20 \mathrm{mM}$ HEPES (pH 7.4 at $37^{\circ} \mathrm{C}$ ), $2 \mathrm{mM} \mathrm{K}$-phosphate buffer (pH 7.4 at $37^{\circ} \mathrm{C}$ ), $120 \mathrm{mM} \mathrm{KCl}, 5 \mathrm{mM}$ pyruvate, $5 \mathrm{mM}$ succinate. The aliquots of mitochondria contained $100 \mu \mathrm{g}$ of protein.

The relative fluorescence of NADH and FAD was calculated as $\left(\mathrm{F}-\mathrm{F}_{0}\right) / \mathrm{F}_{0}$, where $\mathrm{F}_{0}$ is the initial fluorescent signal and $\mathrm{F}$ is the signal at the corresponding time period.

In experiments on rotenone, antimycin and A23187, a Ca ${ }^{2+}$-ionophore, the intrinsic fluorescence of these compounds was taken into account.

Estimation of hydrodynamic diameter of mitochondria. Hydrodynamic diameter of mitochondria was assayed with ZetaSizer 3 multi-angle particle size analyzer (Malvern Instruments, Great Britain) equipped with computing correlator type 7032 and He-Ne laser LHN-111 with $\lambda=633 \mathrm{~nm}$ and $25 \mathrm{~mW}$ output. Autocorrelation of laser light scattering on mitochondria suspension was registered for $1 \mathrm{~min}$, in 10 series under $90^{\circ}$ scattering angle. The autocorrelation function was calculated with standard PCSSize mode v. 1.61 software. The incubation medium $(1 \mathrm{ml})$ was of the composition described above. Mitochondrial function was aliquoted at $50 \mu \mathrm{l}$, which corresponded to $50 \mu \mathrm{g}$ of protein.

We used the following reagents: HEPES, sodium pyruvate, sodium succinate, rotenone, antimycin A, CCCP, $\mathrm{NaN}_{3}$, A23187, ATP, bovine serum albumin (Sigma, USA), mineral salts of local origin. The reagents were dissolved in $\mathrm{ddH}_{2} \mathrm{O}$ with specific conductance no higher than $1.5 \mu \mathrm{S} / \mathrm{cm}$, as measured by OK-102/1 conductometer (Hungary).

Data are presented as mean \pm SEM; significant differences between group were evaluated by using Student's $t$-test with $P<0.05$ [26].

\section{Results and Discussion}

Analysis of emission and excitation spectra of NADH and FAD in mitochondria fraction of rat uterus smooth muscle cells. We investigated spectrum of NADH fluorescence in mitochondria fraction at excitation wavelength of $350 \mathrm{~nm}$ (as determined by others) [21]. We observed two maximums of fluorescence at $400 \mathrm{~nm}$ and $450 \mathrm{~nm}$ (Fig. 2). At emission wavelength of 400 or $450 \mathrm{~nm}$ we deter- mined two maximums of excitation - at $280 \mathrm{~nm}$ and $350 \mathrm{~nm}$. As shown by others, the excitation maximum at $280 \mathrm{~nm}$ is due to tryptophan residues in protein. At $280 \mathrm{~nm}$ excitation tryptophan fluoresces at $300 \mathrm{~nm}$, yet chemical microenvironment shifts this to a significantly longer wavelength [21, 22, 27, 28]. In this case the maximum of tryptophan fluorescence may be at $400 \mathrm{~nm}$ (Fig. 2).

The maximums of excitation and emission for $\mathrm{NADH}$ in mitochondrial fraction from rat uterus myocytes are $350 \mathrm{~nm}$ and $450 \mathrm{~nm}$, correspondingly (Fig. 2, B, C). The maximums of excitation and fluorescence of FAD were at $450 \mathrm{~nm}$ and $533 \mathrm{~nm}$ (Fig. 3, $B, C)$, which is in accordance with data by others [8-10, 16, 21, 22]. Moreover, excitation and emission spectra of the investigated adenine nucleotides are matching those of working solutions of the corresponding chemically pure nucleotides (Fig. 2, A; 3, $A$ ). It must be noted that NADH binding to proteins prevents contact (stacking) between adenine and reduced nicotinamide group, which causes increase in quantum output of fluorescence, although the corresponding effect for FAD has not been detected [21].

Changes in NADH and FAD fluorescence in mitochondrial fraction in medium with substrates of respiration. We introduced $5 \mathrm{mM}$ pyruvate, a substrate of pyruvate dehydrogenase complex that produced NADH for ETC, and $5 \mathrm{mM}$ succinate, a substrate of FAD-dependent succinate dehydrogenase, into incubation medium in order to produce the energized state of mitochondria.

NADH fluorescence decreased in time in the presence of respiratory substrates, which indicates increase in $\mathrm{NAD}^{+}$content resulting from functioning of NADH-ubiquinone oxidoreductase (complex I) (Fig. 4, A). FADH $_{2}$ content also decreased, with corresponding increase in FAD fluorescence, which reflects the activity of succinate dehydrogenase complex (complex II) of ETC (Fig. 4, B, C). Thus, we observed reciprocity in changes of fluorescence of flavin and pyridine adenine-nucleotides under normal functioning of ETC, which is corroborated by data by others [8-10, 15-17, 29].

Complex II is the key enzymatic component of the citric acid cycle. It catalyzes oxidation of succinate to fumarate in mitochondrial matrix. Succinate oxidation is coupled with reduction of ubiquinone in inner mitochondrial membrane. Complex II is composed of two functional parts. One is the soluble succinate dehydrogenase, containing a $70 \mathrm{kDa}$ subunit that covalently binds FAD, and $30 \mathrm{kDa}$ subunit that incorporates Fe-S clusters. The other is a membrane- 
A

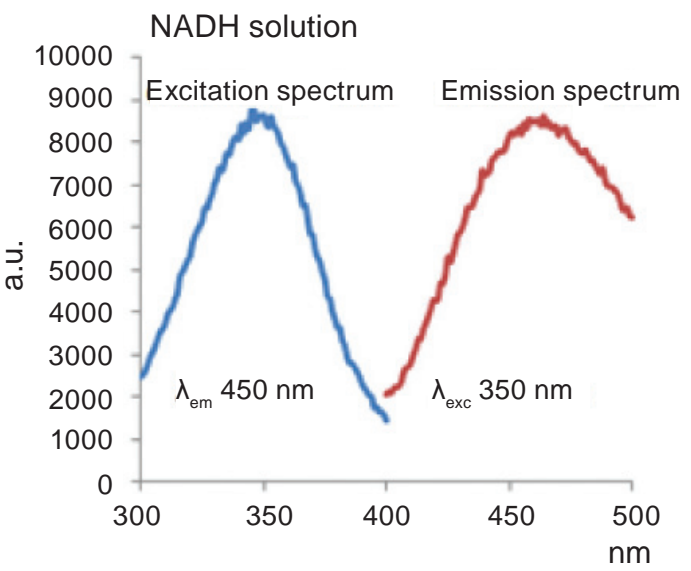

B

NADH excitation spectrum (mitochondria)

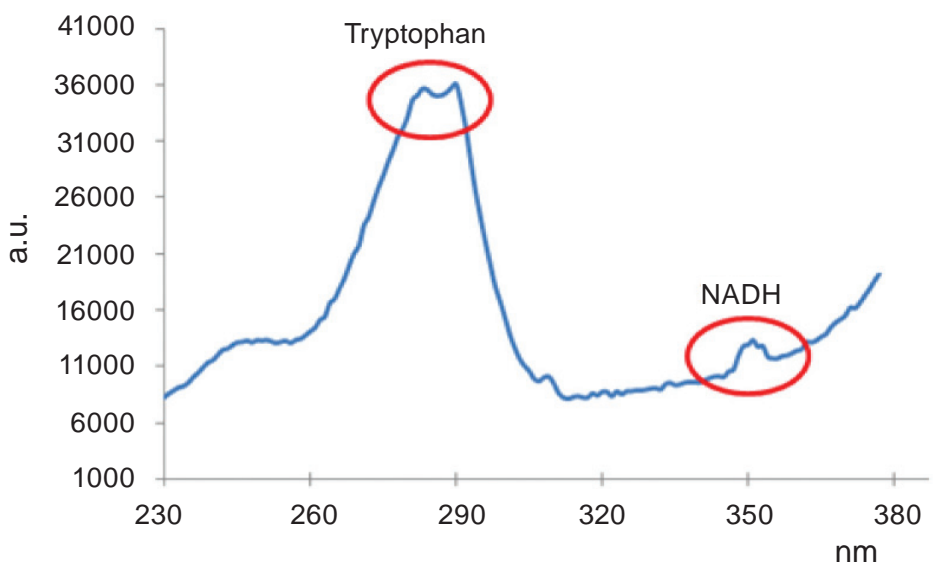

C

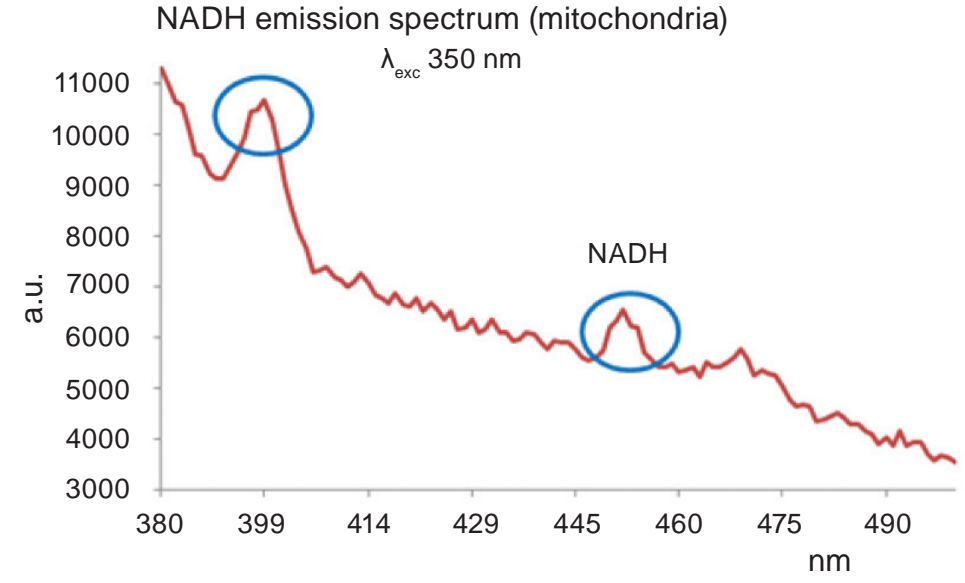

Fig. 2. Excitation and fluorescence spectra of chemically pure $N A D H$ (A, working solution), and of $N A D H$ in mitochondria from rat uterus myocytes $(B, C)$

bound protein composed of two subunits (12 and $9 \mathrm{kDa}$ ) and a heme b. FAD is reduced to $\mathrm{FADH}_{2}$ as a results of succinate oxidation to fumarate by the $70 \mathrm{kDa}$ subunit. Further reduction of ubiquinone (Q), which binds to the $12 \mathrm{kDa}$ subunit, to ubiquinol (QH2) is coupled with $\mathrm{FADH}_{2}$ oxidation.
Decrease in FAD fluorescence caused by introduction of respiratory substrates (Fig. 4, B) or in their presence from the start (Fig. 4, $C$ ) may be explained by stimulation of activity of citric acid cycle enzymes, in particular the succinate dehydrogenase. The prolonged increase in signal that follows may be 
$\boldsymbol{A}$

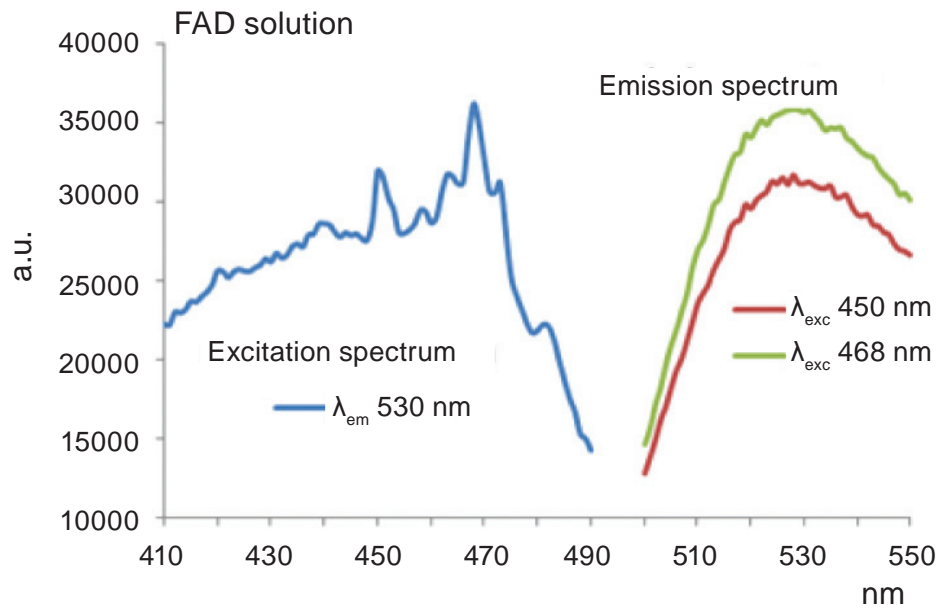

B

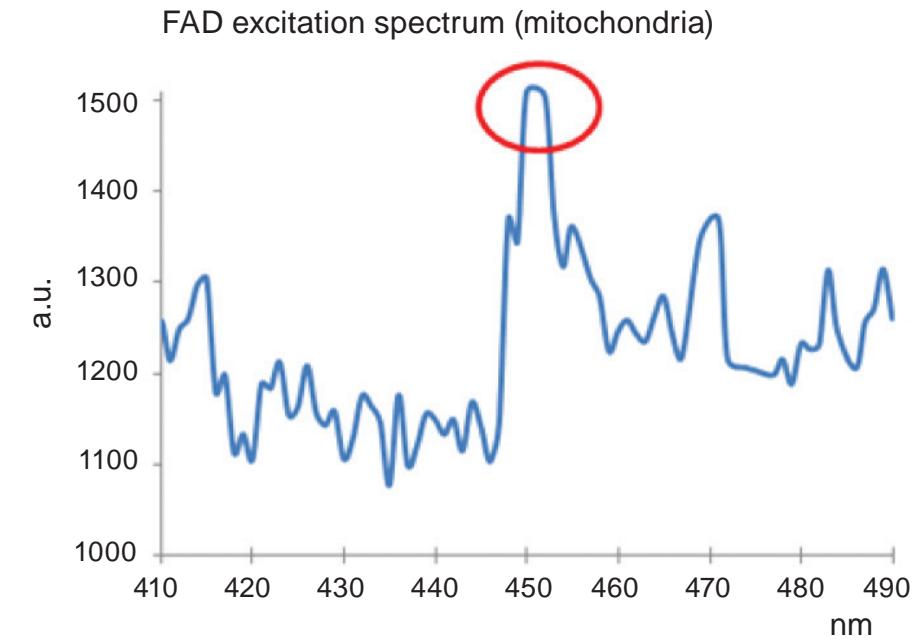

C

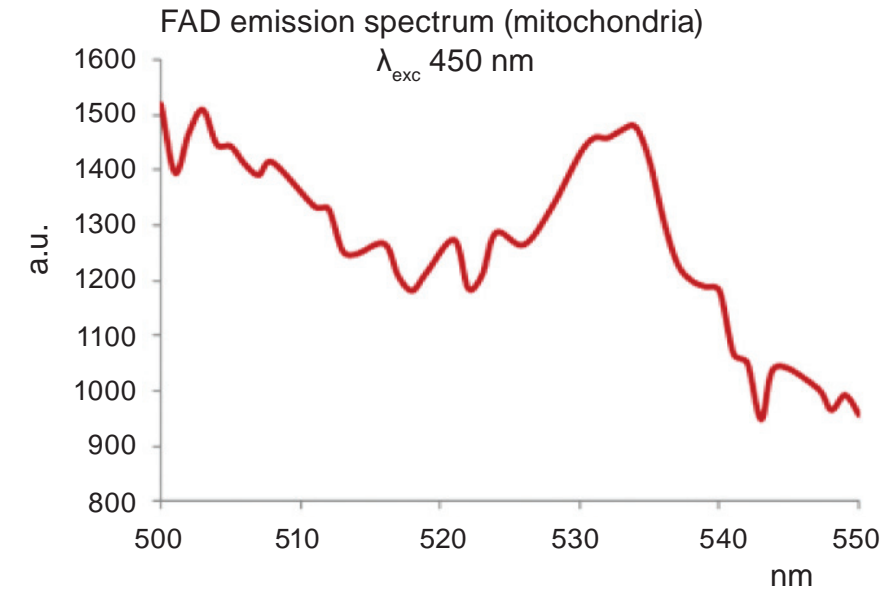

Fig. 3. Excitation and emission spectra of chemically pure FAD (A, working solution), and of NADH in mitochondria from rat uterus myocytes $(B, C)$

due to intensive oxidation of $\mathrm{FADH}_{2}$ resulting from activation of ETC.

Changes in NADH and FAD fluorescence in mitochondria under the effect of ETC inhibitors and CCCP protonophore. Introduction of rotenone
( $5 \mu \mathrm{M}$ ), which blocks ubiquinone binding to complex I, into incubation medium caused increase in NADH content resulting from inhibition of NADH dehydrogenase of complex I that is reflected as increase in fluorescence of the pyridine nucleotide 
$A$

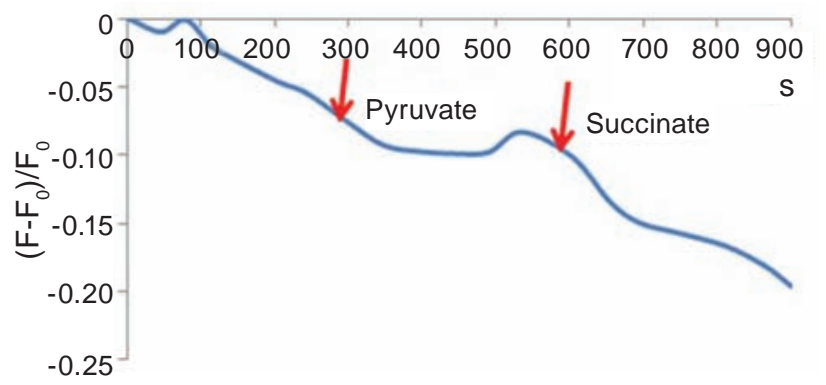

B

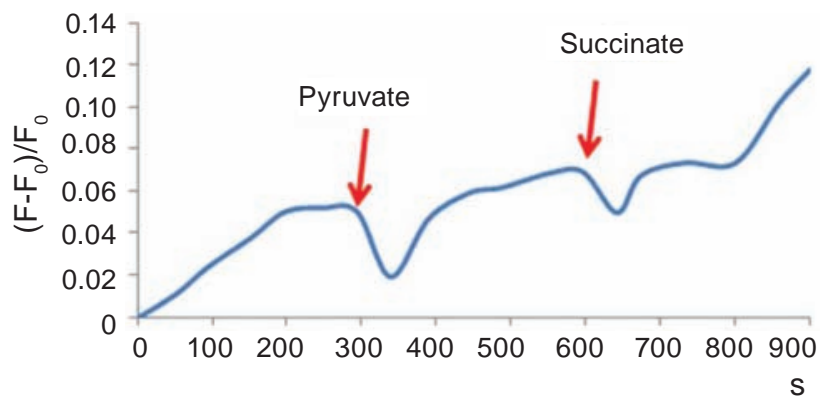

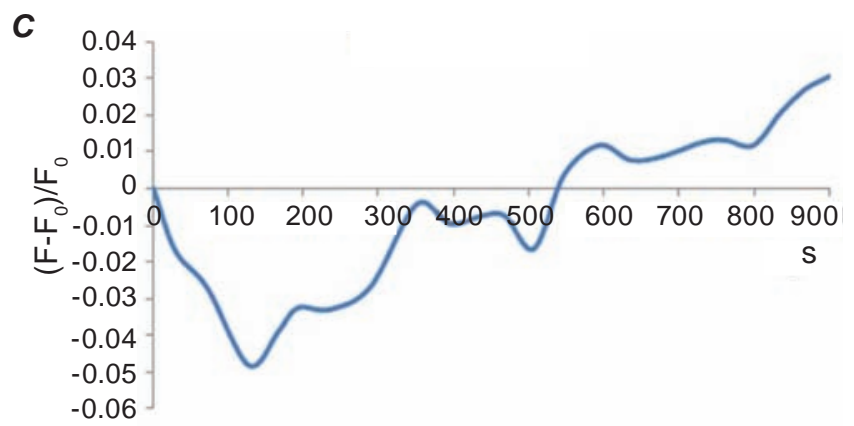

Fig. 4. Changes in NADH (A) and FAD (B) fluorescence in isolated mitochondria of uterus' myocytes in presence of respiratory substrates pyruvate $(5 \mathrm{mM})$ and succinate $(5 \mathrm{mM})$ or after introduction of both the substrates in the incubation medium $(C), n=5$. Data of a typical experiment
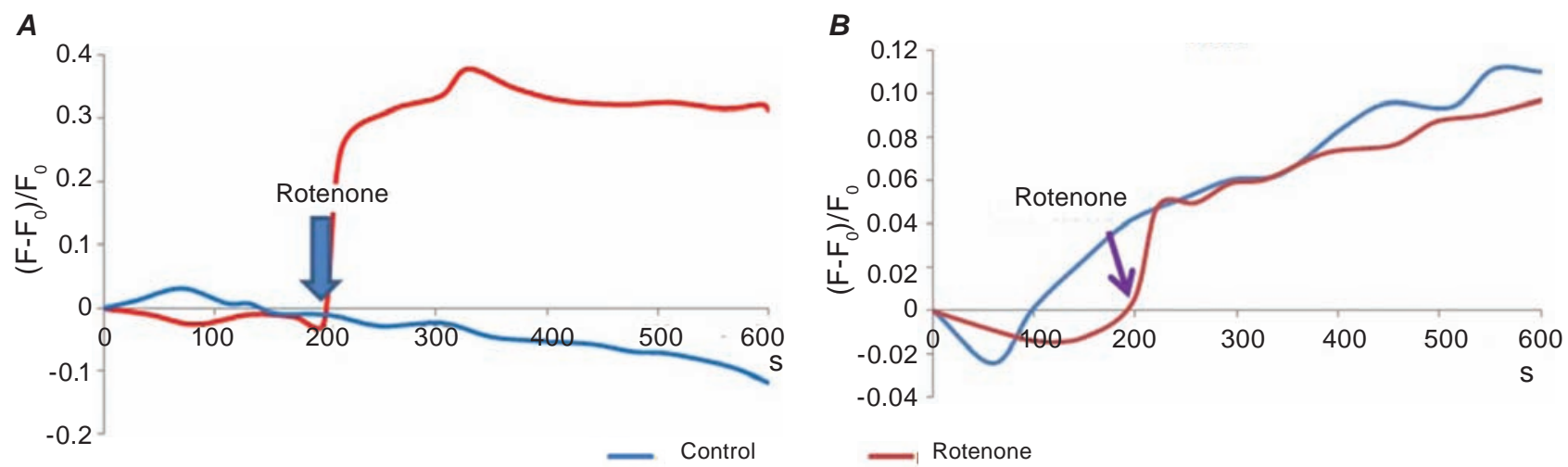

Fig. 5. Changes in NADH (A) and FAD (B) fluorescence in isolated mitochondria of uterus' myocytes in presence of rotenone $(5 \mu M), n=5$. Data of a typical experiment

(Fig. 5, A). This result is in agreement with data obtained on cells from lung, carcinoma, brain neurons, and isolated brain and myocardium mitochondria [5, $10,16,20]$. Rotenone did not affect changes in FAD fluorescence dynamics (Fig. 5, B).

Antimycin $\mathrm{A}$ is an inhibitor of ubiquinone-cytochrome $c$ reductase, the complex III of ETC, and blocks electron transfer from ubiquinone to cytochrome $c[30,31]$.

Introduction of antimycin $(1 \mu \mathrm{g} / \mathrm{ml})$ into incubation medium caused significant increase in inten- sity of NADH fluorescence and moderate increase in FAD fluorescence in comparison to control (Fig. 6). These results indicate inhibition of complex I and decrease in activity of complex II of ETC. In the presence of succinate in incubation medium complex II oxidizes succinate to fumarate and reduces ubiquinone to ubiquinol, albeit less efficiently. Reverse electron transport from succinate to complex I via ubiquinone, which would raise NADH levels, may be also possible under these conditions due to reverse in functioning of NADH-dehydrogenase [5]. 
A

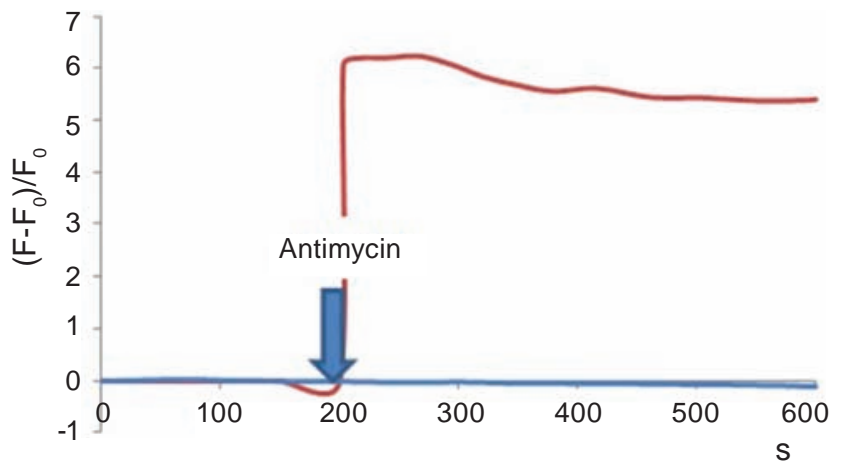

B

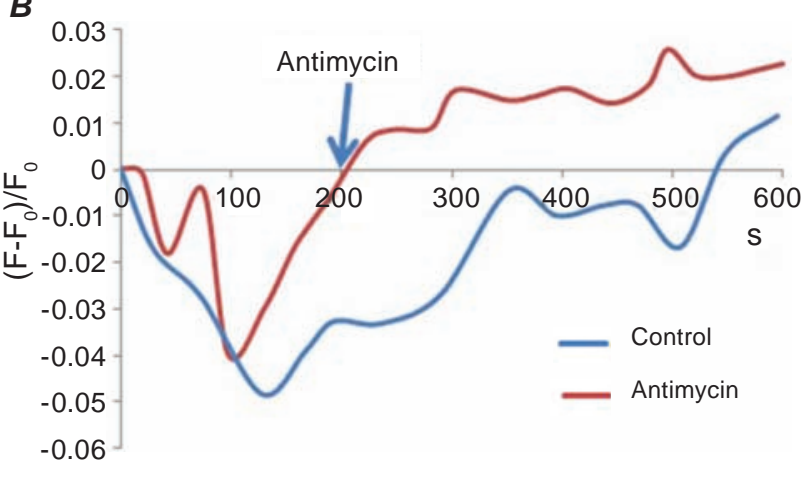

Fig. 6. Effect of antimycin $(1 \mu \mathrm{g} / \mathrm{ml})$ on $\mathrm{NADH}(A)$ and $\mathrm{FAD}(B)$ fluorescence in isolated mitochondria from myocytes of uterus, $n=5$. Data of a typical experiment

A

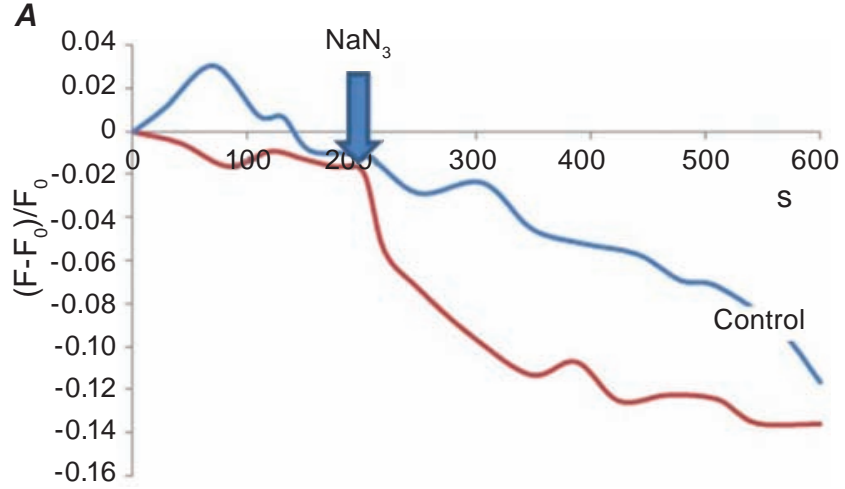

B

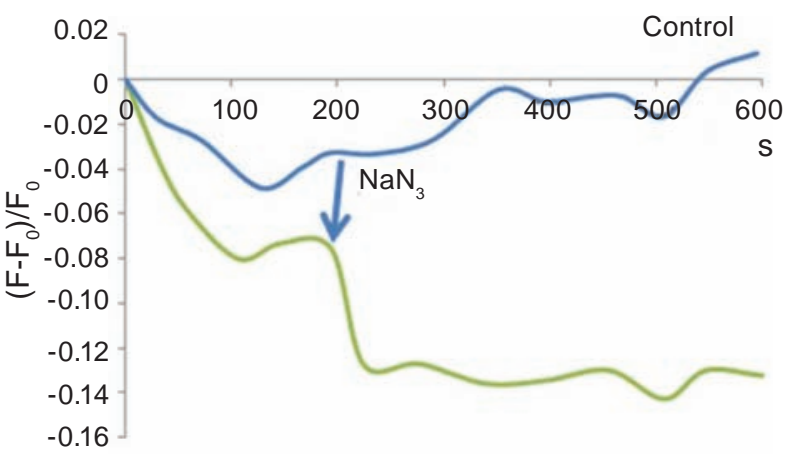

Fig. 7. Effect of sodium azide (5 mM) on NADH (A) and FAD (B) fluorescence in isolated mitochondria from myocytes of uterus, $n=5$. Data of a typical experiment.

Sodium azide $(5 \mathrm{mM})$ caused more pronounced decrease in NADH fluorescence than in control, and also increase in $\mathrm{FADH}_{2}$ contents (Fig. 7), which may indicate blocking of electron transfer from succinate to ubiquinone. Decrease in FAD fluorescence has also been observed on lung cells and Ehrlich carcinoma cells if preincubated with KCN, with simultaneous increase in NADH signal $[6,7]$.

Sodium azide is known to degrade in water solutions, producing hydrazoic acid, hydroxylamine, and, possibly, nitrogen oxides, which act as reactive nitrogen species in biological systems. Hence, sodium azide may be an "indirect NO donor" [32]. The primary effects of NO are: 1) high affinity inhibition of complex IV of ETC, 2) nitrosylation of proteins containing thiol groups in active center (i.e. pyruvate dehydrogenase complex and enzymes of citric acid cycle), 3) nitrosylation of complex I, which results in marked decrease of its activity [33].

On account of these considerations, we investigated changes in fluorescence of NADH and FAD in the presence of sodium nitroprusside and nitrite $(0.1 \mathrm{mM})$. We found the results to be analogous to those of the azide effects (Fig. 8).

Thus, we attribute the decreased NADH and FAD levels under the effect of $\mathrm{NaN}_{3}$ to drop in activity of enzymes of citric acid cycle due to inhibition of ETC in mitochondrial membrane.

Membrane proton gradient dissipation in presence of CCCP protonophore $(10 \mu \mathrm{M})$ resulted in marked decrease in NADH and FAD fluorescence (Fig. 9). Protonophores act to uncouple respiration and oxidative phosphorylation by elimination of $\mathrm{H}^{+}$gradient, resulting in compensatory rise in functional activity of certain elements of mitochondrial ETC [34]. Our results indicate higher complex I activity (NADH fluorescence levels drop rapidly, followed by a slower decrease). Decreased FAD fluorescence indicates block in electron transfer from succinate to ubiquinone. Nevertheless, continued oxidation of succinate by succinate dehydrogenase causes increase in $\mathrm{FADH}_{2}$ levels. 
A

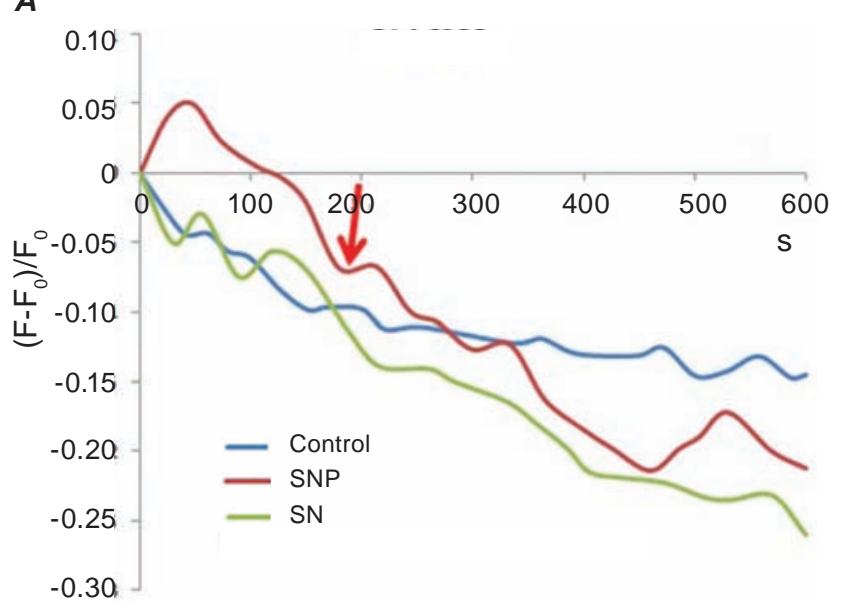

B

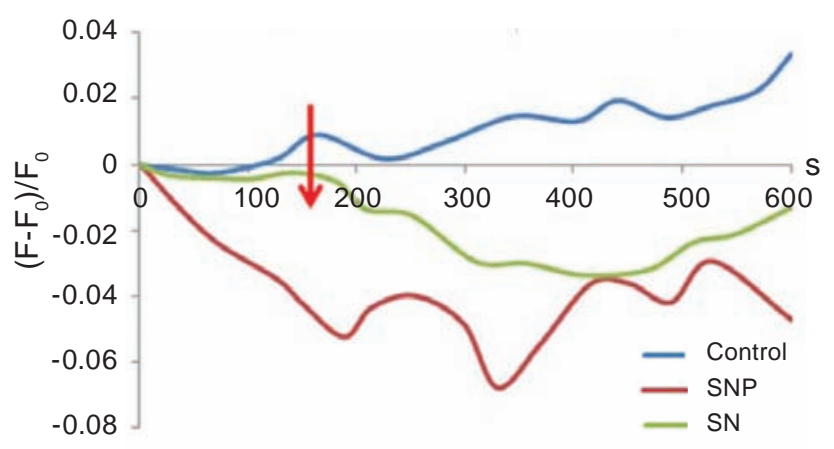

c

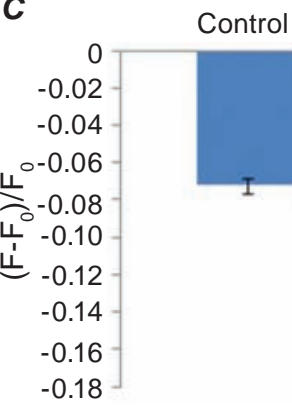

SNP

SN

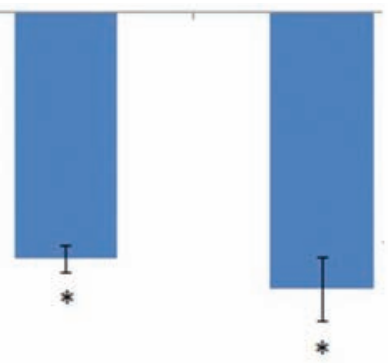

Fig. 8. Effect of nitric oxide donors - sodium nitroprusside (SNP) and nitrite (SN) (0.1 mM) - on NADH (A) and FAD (B) fluorescence in isolated mitochondria from myocytes of uterus. Data of a typical experiment and statistical representation of the experimental results for $N A D H(C)(M \pm m, n=5)$, * denotes significant changes in comparison to control, $P \leq 0.05$. The mean values were calculated from relative fluorescence on the $10^{\text {th }}$ min of incubation
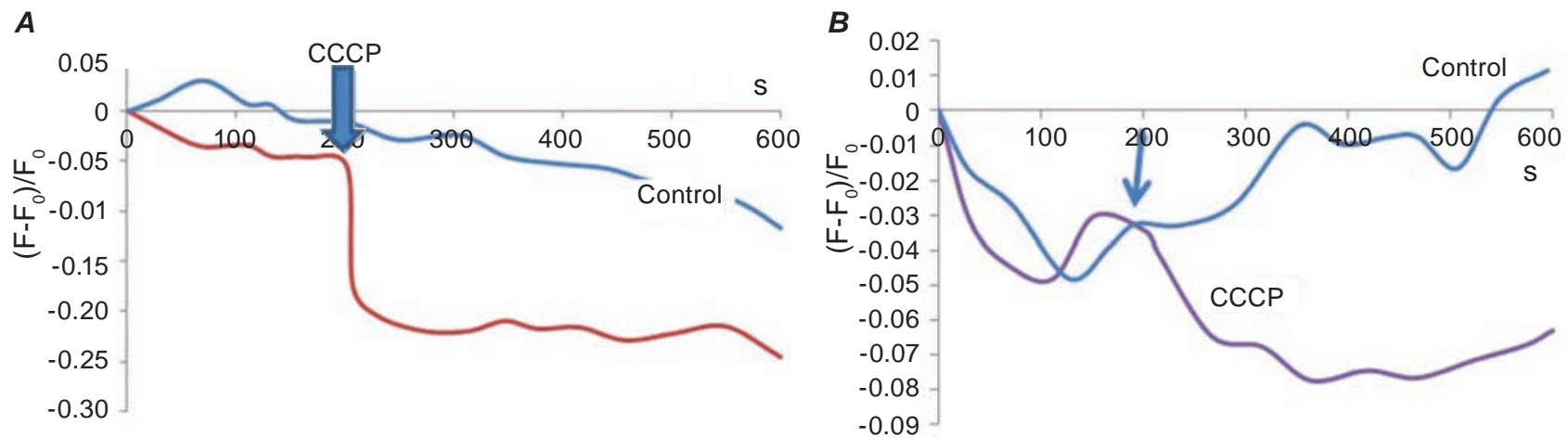

Fig. 9. Effect of CCCP protonophore $(10 \mu M)$ on $N A D H(A)$ and FAD (B) fluorescence in isolated mitochondria from myocytes of uterus, $n=5$. Data of a typical experiment

Preincubation of isolated mitochondria with CCCP protonophore caused a decrease in levels of ionized $\mathrm{Ca}^{2+}$ in matrix of the organelles in our experiments, and also results in release of the $\mathrm{Ca}^{2+}$ that had been accumulated in energy-dependent way in mitochondria. Pyruvate dehydrogenase complex and NAD-containing dehydrogenases of citric acid cycle ( $\alpha$-ketoglutarate dehydrogenase and isocitrate dehydrogenase) are known to be $\mathrm{Ca}^{2+}$-dependent enzymes [35]. Thus, CCCP causes a decrease in 
A

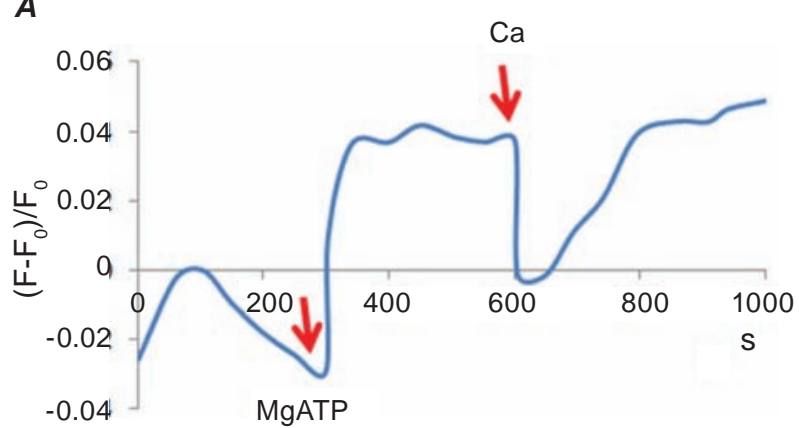

B

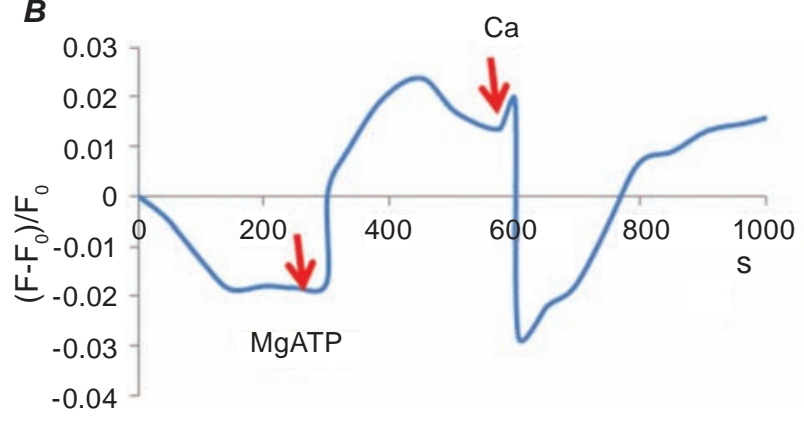

Fig. 10. Effect of $M g-A T P^{2-}(3 \mathrm{mM})$ and $\mathrm{Ca}^{2+}(80 \mu \mathrm{M})$ on $\mathrm{NADH}$ (A) and FAD (B) fluorescence in isolated mitochondria from myocytes of uterus, $n=4$. Data of a typical experiment

mitochondrial matrix Ca ions level, resulting in decreased activity of $\mathrm{Ca}^{2+}$-dependent enzymes of citric acid cycle and succinate dehydrogenase.

Consequently, compensatory restoration of proton gradient is performed primarily by complex I of ETC, since this way is energetically more efficient for mitochondria.

Changes in NADH and FAD fluorescence in the presence of endogenous effectors. Mitochondria has been shown to be deeply involved in processes of intracellular $\mathrm{Ca}^{2+}$ signaling due to their capacity to pool and release $\mathrm{Ca}^{2+}$. $\mathrm{Ca}^{2+}$ uptake by mitochondria is performed by voltage-dependent ruthenium red-sensitive $\mathrm{Ca}^{2+}$ uniporter with optimal activity within micromolar range of extramitochondrial $\mathrm{Ca}^{2+}$ concentrations [36]. Mg-ATP ${ }^{2-}$ and succinate are required to be present in the incubation medium for isolated mitochondria to uptake $\mathrm{Ca}^{2+}$ [37].

Mg-ATP $^{2-}$ addition (artificial energization of mitochondrial membrane) leads to increased NADH and FAD content, which may indicate inhibition of complex I. Addition of $\mathrm{Ca}$ ions $(80 \mu \mathrm{M})$ to incubation medium with its consequent energy-dependent accumulation in mitochondria (in the presence of

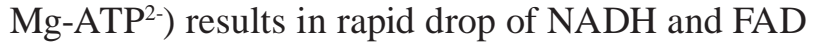
fluorescent signal that may be caused by a decrease in electrochemical potential of the inner mitochondrial membrane (Fig. 10). The subsequent rise in NADH level is associated primarily with $\mathrm{Ca}^{2+}$-dependent activation of citric acid cycle dehydrogenases and pyruvate dehydrogenase complex [35]. The increase in FAD fluorescence resulting from stimulation of $\mathrm{Ca}^{2+}$ transport in matrix may indicate intensification of ETC performance, in particular that of complex II. Introduction of $\mathrm{Ca}^{2+}$-ionophore
A23187 $(10 \mu \mathrm{M})$ caused more pronounced increase in fluorescence of the investigated nucleotides (data not shown).

Effect of ETC inhibitors on hydrodynamic diameter of mitochondria. Swelling is important morphologic sign of mitochondria damage [38]. Mitochondria analysis is done by various means. Photon correlation spectroscopy is widely employed to determine the characteristic particle size (hydrodynamic diameter) of mitochondria. The mean hydrodynamic diameter of control mitochondria was $547 \pm 49 \mathrm{~nm}$, which is within their effective size $[39,40]$. Alamethicin addition $(7.5 \mu \mathrm{g} / \mathrm{ml})$ leads to the increase of hydrodynamic diameter to $773 \pm 32 \mathrm{~nm}$. Alamethicin is used as the potentially least damaging agent for permeabilization of the inner mitochondria membrane [39]. Alamethicin produces pores with various permeability characteristics as a result of aggregation of its peptides. It is important to mention that beyond the permeabilization of membranes, alamethicin does not disrupt the inner or the outer membrane, activity of complex I of ETC and ATP synthase complex, and does not inhibits citric acid cycle enzymes' activity (aconitase and isocitrate dehydrogenase) [41]. Changes in hydrodynamic diameter after introduction of alamethicin were taken as control values (100\% swelling).

The inhibitors of ETC we used - rotenone, antimycin, sodium azide, protonophore CCCP caused the increase of hydrodynamic diameter of mitochondria by $40 \%$ on average in comparison to control swelling in presence of alamethicin. Therefore, inhibition of the corresponding complexes of ETC impairs its function resulting in drop in electrochemical inner membrane potential. This causes 
disruptions in transmembrane cation exchange, in particular potassium and $\mathrm{P}_{\mathrm{i}}$, which results in organelle's swelling [42].

Thus, the results of this work, which was performed on fraction of isolated mitochondria from smooth muscle of uterus, demonstrate the possibility to analyze the functional activity of ETC by intrinsic fluorescence of NADH and FAD coenzymes. Changes in their fluorescence in conditions when their mitochondrial content is stable reflect the changes in oxidation and reduction state of these compounds resulting from activity of the corresponding ETC complexes.

The reciprocity of changes in fluorescence of the pyridine and the flavin nucleotides under normal mitochondrial ETC functioning was demonstrated in the presence of substrates for complex I and II. In these conditions we observed a decrease in NADH signal and increase in FAD signal, which may serve as a test for ETC functioning.

Analysis of fluorescent response of NADH and FAD in isolated mitochondria to specific inhibition of complexes I, III and IV of ETC, and to addition of protonophore revealed the correlation between changes in fluorescence of the investigated nucleotides (their redox state) and function of the particular complexes in ETC of the inner mitochondrial membrane.

Measurements of FAD and NADH fluorescent signal may be used to assay response to effectors of ETC functioning. We demonstrated that increased energization of mitochondria causes inhibition of complex I of ETC, and that higher $\mathrm{Ca}^{2+}$ accumulation results in increased FAD and NADH fluorescence reflecting activation of $\mathrm{Ca}^{2+}$-dependent activation of NAD-containing dehydrogenases of citric acid cycle and succinate dehydrogenase complex.

The perceived absence of the direct link between effects of chemical compounds on the particular elements of ETC and the fluorescent signal from endogenous mitochondrial nucleotides may be problematic for applications of our approach. This is due to ETC functioning as a single self-regulating system, its efficiency greatly depending on activity of the citric acid cycle enzymes. Hence it is important to continue this line of research with the aim of establishing correlation between effects of a large number of ETC modulators and the fluorescent response. The primary goal of the further work will be establishing connections between ETC, nucleotide fluorescence and functional activity of mitochondria, in particular their cation transport and polarization of the inner membrane.

Nevertheless, we consider the methodology of this study to be of value for research on functional state of mitochondria under normal conditions and under effect of modifiers of ion exchange and mitochondrial enzyme activity.

The author is grateful to Prof., Dr. S. O. Kosterin, Dr. Sc. Iu. V. Danylovych, and Dr. O. Iu. Chunikhin for their help in performing the experiments and participation in discussions of results.

\section{ОЦІНКА ФУНКЦІОНУ ВАННЯ ЕЛЕКТРОНТРАНСПОРТУВАЛЬНОГО ЛАНЦЮГА МІТОХОНДРІЙ МIOMЕТРІЯ ЗА АВТОФЛУОРЕСЦЕНЦІЕЮ NADH TA FAD}

\section{Г. В. Данилович \\ Інститут біохімії ім. О. В. Палладіна НАН України, Київ; e-mail: danylovych@biochem.kiev.ua}

Доведено можливість дослідження функціонування електронтранспортувального ланцюга в ізольованих мітохондріях гладенького м'яза матки щурів за використання власної флуоресценції коензимів NADH та FAD. Виявлено протилежно спрямовані зміни флуоресцентних сигналів від FAD та від NADH за нормального функціонування електронтранспортувального ланцюга мітохондрій. Спрямований вплив інгібіторів комплексів I, III та IV змінював флуоресценцію аденінових нуклеотидів. Ротенон (5 мкM) спричинював різке зростання флуоресценції NADH внаслідок інгібування комплексу I і не змінював динаміку росту флуоресценції від FAD. Антиміцин А (1 мкг/мл; інгібітор комплексу III) призводив до різкого зростання флуоресценції NADH та помірного зростання iï у FAD порівняно 3 контролем. Інгібітор IV комплексу $\mathrm{NaN}_{3}(5 \mathrm{mM})$ та протонофор СССР (10 мкM) знижували флуоресценцію від NADH та FAD. Крім того, всі вищезазначені інгібітори спричинювали набухання мітохондрій. Донори NO - (0,1 мМ нітропрусид та нітрит натрію) знижували флуоресценцію NADH та FAD подібно до змін флуоресценції за дії азиду натрію. Енергозалежна акумуляція $\mathrm{Ca}^{2+}$ в матрикс мітохондрій (у присутності субстратів окислення та комплексу 
Mg-ATP ${ }^{2-}$ супроводжувалась різким зниженням флуоресценції NADH та FAD із подальшим ростом флуоресценції досліджуваних нуклеотидів, що, можливо, відбувається переважно за рахунок $\mathrm{Ca}^{2+}$-залежної активації дегідрогеназ циклу Кребса. Отже, флуоресцентний сигнал від FAD та NADH відображає зміни окисновідновного стану зазначених нуклеотидів в ізольованих мітохондріях, що можна використати для оцінки впливу ефекторів функціонування електронтранспортувального ланцюга.

К л ю ч о в і с л о в а: електронтранспортувальний ланцюг мітохондрій, NADH, FAD, флуоресценція, інгібітори, міометрій щурів.

\section{ОЦЕНКА ФУНКЦИОНИРОВАНИЯ ЭЛЕКТРОНТРАНСПОРТНОЙ ЦЕПИ МИТОХОНДРИЙ МИОМЕТРИЯ ПО АУТОФЛУОРЕСЦЕНЦИИ NАDН И FAD}

\section{А. В. Данилович}

Институт биохимии им. А. В. Палладина НАН Украины, Киев; e-mail: danylovych@biochem.kiev.ua

Доказана возможность исследования функционирования электронтранспортной цепи в изолированных митохондриях гладкой мышцы матки крыс с использованием собственной флуоресценции коэнзимов NADH и FAD. Показана реципрокность изменений флуоресцентных сигналов от FAD и NADH при нормальном функционировании электронтранспортной цепи митохондрий. Направленное действие ингибиторов I, III и IV комплексов приводило к изменениям флуоресценции исследуемых адениновых нуклеотидов. Ротенон (5 мкM) вызывал резкое увеличение флуоресценции NADH вследствие ингибирования комплекса I, при этом не изменяя динамику увеличения флуоресценции FAD. Антимицин А (1 мкг/мл; ингибитор III комплекса) вызывал резкое увеличение флуоресценции $\mathrm{NADH}$ и умеренное в сравнении с контролем от FAD. Ингибитор IV комплекса $\mathrm{NaN}_{3}(5$ мM) и протонофор СССР (10 мкМ) приводили к снижению флуоресценции от NADH и FAD. Кроме того, все использованные ингибиторы вызывали набухание митохондрий. Доноры $\mathrm{NO}-(0,1 \mathrm{мM}$ нитропруссид и нитрит натрия), вызывали снижение флуоресценции NADH и FAD подобно из- менениям флуоресценции при действии азида натрия. Энергозависимая аккумуляция $\mathrm{Ca}^{2+}$ в матрикс митохондрий (в присутствии субстратов окисления и комплекса $\mathrm{Mg}$-ATP ${ }^{2-}$ ) сопровождалась резким снижением флуоресценции NADH и FAD с дальнейшим ростом флуоресценции адениновых нуклеотидов, что возможно происходит преимущественно за счет $\mathrm{Ca}^{2+}$-зависимой активации дегидрогеназ цикла Кребса. Таким образом, флуоресцентный сигнал от FAD и $\mathrm{NADH}$ отображает изменения окислительновосстановительного состояния исследуемых нуклеотидов в изолированных митохондриях, что можно использовать для оценки влияния эффекторов функционирования электронтранспортной цепи.

К л ю ч е в ы е с л о в а: электронтранспортная цепь митохондрий, NADH, FAD, флуоресценция, ингибиторы, миометрий крыс.

\section{References}

1. Shiryaeva A. P., Baydyuk E. V., Arkadieva A. V., Morozov V. I., Sakuta G. A., Okovityi S. V. Hepatocyte mitochondrion respiratory chain in rats with experimental toxic hepatitis. Tsitologiya. 2007; 49(2): 125-132. (In Russian).

2. Manko B. O., Manko V. V. Influence of $\mathrm{Ca}^{2+}$ on kinetic parameters of pancreatic acinar mitochondria in situ respiration. Ukr. Biokhim. Zhurn. 2013; 85(4): 48-60. (In Ukrainian).

3. Man'ko B. O., Man'ko V. V. Influence of adenosine diphosphate on respiration of rat pancreatic acinar cells mitochondria in situ. Fiziol. Zhurn. 2013; 59(5): 61-70. (In Ukrainian).

4. Akopova O. V., Kolchinskaya L. I., Nosar V. I., Buryi V. A., Mankovska I. N., Sagach V. F. The effect of ATP-dependent $\mathrm{K}(+)$-channel opener on transmembrane potassium exchange and reactive oxygen species production upon the opening of mitochondrial pore. Ukr. Biochem. J. 2014; 86(2): 26-40. (In Russian).

5. Agarwal B., Dash R. K., Stowe D. F., Bosnjak Z. J., Camara A. K. Isoflurane modulates cardiac mitochondrial bioenergetics by selectively attenuating respiratory complexes. Biochim. Biophys. Acta. 2014; 1837(3): 354-365.

6. Heikal A. A. Intracellular coenzymes as natural biomarkers for metabolic activities and mitochondrial anomalies. Biomark. Med. 2010; 4(2): 241-263. 
7. Skala M. C., Riching K. M., GendronFitzpatrick A., Eickhoff J., Eliceiri K. W., White J. G., Ramanujam N. In vivo multiphoton microscopy of NADH and FAD redox states, fluorescence lifetimes, and cellular morphology in precancerous epithelia. Proc. Natl. Acad. Sci. USA. 2007; 104(49): 19494-19499.

8. Wang H. W., Wei Y. H., Guo H. W. Reduced nicotinamide adenine dinucleotide (NADH) fluorescence for the detection of cell death. Anticancer Agents Med. Chem. 2009; 9(9): 10121017.

9. Kosterin P., Kim G. H., Muschol M., Obaid A. L., Salzberg B. M. Changes in FAD and NADH fluorescence in neurosecretory terminals are triggered by calcium entry and by ADP production. J. Membr. Biol. 2005; 208(2): 113124.

10. Shuttleworth C. W., Brennan A. M., Connor J. A. $\mathrm{NAD}(\mathrm{P}) \mathrm{H}$ fluorescence imaging of postsynaptic neuronal activation in murine hippocampal slices. J. Neurosci. 2003; 23(8): 3196-3208.

11. Schaue D., Ratikan J. A., Iwamoto K. S. Cellular autofluorescence following ionizing radiation. PLoS One. 2012; 7(2): e32062.

12. Daiber A. Redox signaling (cross-talk) from and to mitochondria involves mitochondrial pores and reactive oxygen species. Biochim. Biophys. Acta. 2010; 1797(6-7): 897-906.

13. Schafer F. Q., Buettner G. R. Redox environment of the cell as viewed through the redox state of the glutathione disulfide/glutathione couple. Free Radic. Biol. Med. 2001; 30(11): 1191-1212.

14. Shuttleworth C. W. Use of NAD(P)H and flavoprotein autofluorescence transients to probe neuron and astrocyte responses to synaptic activation. Neurochem. Int. 2010; 56(3): 379-386.

15. Shah A. T., Demory Beckler M., Walsh A. J., Jones W. P., Pohlmann P. R., Skala M. C. Optical metabolic imaging of treatment response in human head and neck squamous cell carcinoma. PLoS One. 2014; 9(3): e90746.

16. Staniszewski K., Audi S. H., Sepehr R., Jacobs E. R., Ranji M. Surface fluorescence studies of tissue mitochondrial redox state in isolated perfused rat lungs. Ann. Biomed. Eng. 2013; 41(4): 827-836.

17. Stowe D. F., Gadicherla A. K., Zhou Y., Aldakkak M., Cheng Q., Kwok W. M., Jiang M. T., Heisner J. S., Yang M., Camara A. K. Protection against cardiac injury by small $\mathrm{Ca}(2+)$-sensitive
$\mathrm{K}(+)$ channels identified in guinea pig cardiac inner mitochondrial membrane. Biochim. Biophys. Acta. 2013; 1828(2): 427-42.

18. Riess M. L., Camara A. K., Kevin L. G., An J., Stowe D. F. Reduced reactive $\mathrm{O}_{2}$ species formation and preserved mitochondrial NADH and $\left[\mathrm{Ca}^{2+}\right]$ levels during short-term 17 degrees $\mathrm{C}$ ischemia in intact hearts. Cardiovasc. Res. 2004; 61(3): 580-590.

19. Brachmanski M., Gebhard M. M., Nobiling R. Separation of fluorescence signals from $\mathrm{Ca}^{2+}$ and NADH during cardioplegic arrest and cardiac ischemia. Cell Calcium. 2004; 35(4): 381-391.

20. Zinchenko V. P., Goncharov N. V., Teplova V. V, Kasymov V. A., Petrova O. I., Berezhnov A. V., Senchenkov E. V., Mindukshev I. V., Jenkins R. O., Radilov A. S. Studies of interaction of intracellular signalling and metabolic pathways under inhibition of mitochondrial aconitase with fluoroacetate. Tsitologiya. 2007; 49(12): 10231031. (In Russian).

21. Lakowicz J. R. Principles of fluorescence spectroscopy. Second edition. Plenium Publisher, New York, 1999.

22. Islam M. S., Honma M., Nakabayashi T., Kinjo M., Ohta N. pH dependence of the fluorescence lifetime of FAD in solution and in cells. Int. J. Mol .Sci. 2013; 14(1): 1952-1963.

23. Michelini L. G., Benevento C. E., Rossato F. A., Siqueira-Santos E. S., Castilho R. F. Effects of partial inhibition of respiratory complex I on $\mathrm{H}_{2} \mathrm{O}_{2}$ production by isolated brain mitochondria in different respiratory states. Neurochem. Res. 2014; 39(12): 2419-30.

24. Kosterin S. A., Bratkova N. F., Kursky M. D. The role of sarcolemma and mitochondria in calcium-dependent control of myometrium relaxation. Biokhimiia. 1985; 50(8): 1350-1361. (In Russian).

25. Bradford M. M. A rapid and sensitive method for the quantitation of microgram quantities of protein utilizing the principle of protein-dye binding. Anal. Biochem. 1976; 72: 248-54.

26. Bailay N. T. J. Statistical methods in biology. Great Britain: Cambridge University Press; 1995.

27. Vivian J. T., Callis P. R. Mechanisms of tryptophan fluorescence shifts in proteins. Biophys. J. 2001; 80(5): 2093-2109.

28. Postnikova G. B., Shekhovtsova E. A. Fluorescence studies on the interaction of myoglobin 
with mitochondria. Biochemistry (Mosc). 2012; 77(3): 280-287.

29. Ying W. NAD $/ / \mathrm{NADH}$ and $\mathrm{NADP}^{+} / \mathrm{NADPH}$ in cellular functions and cell death: regulation and biological consequences. Antioxid. Redox. Signal. 2008; 10(2): 179-206.

30. Trumpower B. L. The protonmotive Q cycle. Energy transduction by coupling of proton translocation to electron transfer by the cytochrome bc1 complex. J. Biol. Chem. 1990; 265(20): 11409-11412.

31. Hunte C., Palsdottir H., Trumpower B. L. Protonmotive pathways and mechanisms in the cytochrome bc1 complex. FEBS Lett. 2003; 545(1): 39-46.

32. Iakovenko I. N., Zhirnov V. V. Sodium azide as indirect nitric oxide donor: researches on the rat aorta isolated segments. Ukr. Biokhim. Zhurn. 2005; 77(4): 120-123. (In Russian).

33. Zaobornyj T., Ghafourifar P. Strategic localization of heart mitochondrial NOS: a review of the evidence. Am. J. Physiol. Heart Circ. Physiol. 2012; 303(11): H1283-H1293.

34. Watzke N., Diekert K., Obrdlik P. Electrophysiology of respiratory chain complexes and the ADP-ATP exchanger in native mitochondrial membranes. Biochemistry. 2010; 49(48): 1030810318.

35. Gellerich F. N., Gizatullina Z., Trumbeckaite S., Nguyen H. P., Pallas T., Arandarcikaite O., Vielhaber S., Seppet E., Striggow F. The regulation of OXPHOS by extramitochondrial calcium. Biochim. Biophys. Acta. 2010; 1797(67): 1018-1027.
36. Csordas G., Varnai P., Golenar T., Sheu S. S., Hajnoczky G. Calcium transport across the inner mitochondrial membrane: molecular mechanisms and pharmacology. Mol. Cell. Endocrinol. 2012; 353(1-2): 109-113.

37. Kolomiets O. V., Danylovych Yu. V., Danylovych H. V., Kosterin S. O. $\mathrm{Ca}^{2+} / \mathrm{H}^{+}-$ exchange in myometrium mitochondria. Ukr. Biochem. J. 2014; 86(3): 41-48. (In Ukrainian).

38. Kostyuk P. G., Kostyuk O. P., Lukyanets E. A. Intracellular calcium signaling: structures and functions. Kiev: Naukova dumka, 2010. 175 p. (In Ukrainian).

39. Ponomarenko O. V., Babich L. H., Horchev V. F., Kosterin S. O. Studies of $\mathrm{Ca}^{2+}$-dependent smooth muscle mitochondria swelling using flow cytometry and spermine effects on this process. Ukr. Biokhim. Zhurn. 2006; 78(6): 3845. (In Ukrainian).

40. Kandaurova N. V., Chunikhin A. Ju., Babich L. G., Shlykov S. G., Kosterin S. O. Modulators of transmembrane calcium exchange in myometrium mitochondria change their hydrodynamic diameter. Ukr. Biokhim. Zhurn. 2010; 82(6): 52-57. (In Ukrainian).

41. Gostimskaya I. S., Grivennikova V. G., Zharova T. V., Bakeeva L. E., Vinogradov A. D. In situ assay of the intramitochondrial enzymes: use of alamethicin for permeabilization of mitochondria. Anal. Biochem. 2003; 313(1): 4652.

42. Vadziuk O. B. ATP-sensitive $\mathrm{K}^{+}$-channels in muscle cells: features and physiological role. $U k r$. Biochem. J. 2014; 86(3): 5-22. (In Ukrainian).

Received 10.09.2015 